IZA DP No. 8327

Do Immigrants Work in Worse Jobs than U.S. Natives? Evidence from California

Madeline Zavodny

July 2014 


\title{
Do Immigrants Work in Worse Jobs than U.S. Natives? Evidence from California
}

\author{
Madeline Zavodny \\ Agnes Scott College \\ and IZA
}

Discussion Paper No. 8327

July 2014

IZA

P.O. Box 7240

53072 Bonn

Germany

Phone: +49-228-3894-0

Fax: +49-228-3894-180

E-mail: iza@iza.org

Any opinions expressed here are those of the author(s) and not those of IZA. Research published in this series may include views on policy, but the institute itself takes no institutional policy positions. The IZA research network is committed to the IZA Guiding Principles of Research Integrity.

The Institute for the Study of Labor (IZA) in Bonn is a local and virtual international research center and a place of communication between science, politics and business. IZA is an independent nonprofit organization supported by Deutsche Post Foundation. The center is associated with the University of Bonn and offers a stimulating research environment through its international network, workshops and conferences, data service, project support, research visits and doctoral program. IZA engages in (i) original and internationally competitive research in all fields of labor economics, (ii) development of policy concepts, and (iii) dissemination of research results and concepts to the interested public.

IZA Discussion Papers often represent preliminary work and are circulated to encourage discussion. Citation of such a paper should account for its provisional character. A revised version may be available directly from the author. 
IZA Discussion Paper No. 8327

July 2014

\section{ABSTRACT}

\section{Do Immigrants Work in Worse Jobs than U.S. Natives? Evidence from California}

In the debate over immigration reform, it is frequently asserted that immigrants take jobs that U.S. natives do not want. Using data from the 2000 Census merged with O*NET data on occupation characteristics, I show that the jobs held by immigrants are more physically arduous than the jobs held by U.S. natives. However, data from the California Work and Health Survey on self-reported physical job demands indicate that immigrants do not perceive their jobs as requiring more physical effort than U.S. natives. Immigrants thus have worse jobs than natives but do not view them as such.

JEL Classification: J81, J15

Keywords: immigrants, working conditions, compensating differentials

Corresponding author:

Madeline Zavodny

Agnes Scott College

141 E. College Ave.

Decatur, GA 30030

USA

E-mail: mzavodny@agnesscott.edu 


\section{Do Immigrants Work in Worse Jobs than U.S. Natives?}

\section{Introduction}

It is commonly believed that immigrants, particularly low-skilled and unauthorized immigrants, work in jobs that U.S. natives are unwilling to take. This view appears to underlie many immigration policy proposals. For example, when backing comprehensive immigration reform in 2007, President George Bush stated, “If you're going to come and do jobs Americans aren't doing, here is a opportunity to do so. ${ }^{1}$ Understanding whether immigrants accept jobs that natives are unwilling to take is important for understanding immigration's impact on the labor market as well as for designing immigration policy. The more similar immigrants and natives are in terms of their skills and attitudes toward working conditions, the more substitutable immigrants are for natives and the more adverse their labor market impact.

Although there is a large literature on immigration's labor market impact in the United States, there is little empirical evidence on whether immigrants hold jobs that U.S. natives are unwilling to take, and, if so, why. Differences in the distributions of immigrants and natives across industries and occupations are well documented (e.g., Borjas 1999), but few studies have examined immigrant-native differences in job requirements or workplace amenities. Peri and Sparber (2009) show that less-educated immigrants are more likely than U.S. natives to work in occupations that require greater manual dexterity relative to communications skills, and this difference shrinks as immigrants' duration of U.S. residence increases. Hamermesh (1998) finds few differences in workplace amenities between immigrants and U.S. natives after controlling for differences in education and other observable characteristics and concludes that there is no evidence that immigrants hold worse jobs than similar natives.

\footnotetext{
${ }^{1}$ http://www.whitehouse.gov/news/releases/2007/05/20070529-7.html
} 
A related literature examines immigrant-native differences in fatality and injury rates. Orrenius and Zavodny (2009) show that immigrants as a whole worked in jobs with higher fatality and injury rates than U.S. natives during 2003-2005. Hersch and Viscusi (2010) conclude that Mexican immigrants had higher workplace fatality rates than natives during 2003-2005, although other immigrants did not. Dávila, Mora, and González (2011) likewise show that Hispanic immigrant men worked in occupations with higher fatality and injury rates than natives during 1999-2000. Berger and Gabriel (1991), in contrast, find that immigrants were employed in industries with lower average fatality rates than natives in 1980, and Hamermesh (1998) shows that immigrants did not work in industries with higher injury rates than white natives in 1991. The varying time periods used in these studies may account for the differences in their results.

This study adds to the literature a detailed examination of whether immigrants are more likely than natives to work in jobs that are more physically demanding. Although physical job requirements are not as important from a policy perspective as workplace fatalities and injuries, they are nonetheless interesting. Sectors with greater physical requirements also are sectors that tend to entail more workplace risks, such as construction, mining, and agriculture. ${ }^{2}$ In addition, both objective and subjective data on physical work intensity are available. One of the datasets used here gives expert, objective measures of physical job requirements while the other gives self-reported, subjective measures of similar variables. These data can answer the intriguing question of whether immigrants and natives have different perceptions of working conditions. Understanding whether and why immigrants hold more physically arduous jobs—jobs that many

\footnotetext{
${ }^{2}$ The Spearman rank correlation coefficient between physical job requirements as measured by the O*NET using the seven measures discussed below and occupational fatality rates is 0.376 , and 0.639 for occupational injury and illness rates. Both correlations are significantly different from zero below the 1 percent level. The occupational fatality and injury and illness data are from the Bureau of Labor Statistics (BLS) and were converted into rates using occupational employment levels from the BLS Occupational Employment Statistics program.
} 
Americans may perceive as undesirable —is important if immigration policy presumes that foreign-born workers hold jobs that natives are unwilling to take.

The next section provides a brief overview of reasons why immigrants might hold more physically demanding jobs than natives. The data and methods used to examine immigrantnative differentials in physical job requirements are then discussed. The results indicate that immigrants are more likely than natives to work in occupations that objectively require greater physical effort. Subjective data, in contrast, indicate that perceptions of physical job requirements are not higher among immigrants than among U.S. natives.

\section{Reasons for Immigrant-Native Differentials}

There are several reasons why immigrants might be more likely to hold jobs that require greater physical effort. First, immigrants tend to have less human capital than U.S. natives. In 2000, one third of foreign-born workers lacked a high school diploma or equivalent, compared with 12 percent of natives. About 83 percent of foreign-born workers spoke a language other than English at home, with 30 percent of those reporting speaking English not well or not at all. ${ }^{3}$ Low levels of education and limited English skills are likely to restrict many immigrants from holding white-collar jobs that typically require relatively little physical effort. Limited transferability of occupation-specific skills, such as licenses and certifications acquired abroad, may also prevent some immigrants, particularly recent arrivals, from holding relatively skilled jobs with few physical demands.

Immigrants who lack legal status or have recently arrived in the U.S. might be especially likely to hold physically arduous jobs. Enchautegui (2008) shows that unauthorized and recent immigrants report their jobs as worse than other immigrants along a wide variety of dimensions.

\footnotetext{
${ }^{3}$ Author's calculations based on all employed individuals in the 2000 Census.
} 
Unauthorized and recent immigrants may lack the social capital necessary to find a "good" job and therefore may have more limited options in the labor market (Aguilera and Massey 2003). In addition, young men dominate the inflow of unauthorized migrants; these young men are likely to be better able to withstand physically demanding jobs than older or female workers. Relatedly, the "healthy immigrant effect," which argues that immigrants tend to be healthier upon arrival than natives (e.g., Antecol and Bedard 2006), may contribute to immigrants, particularly recent immigrants, holding more physically demanding jobs than U.S. natives.

The theory of compensating differentials offers another potential reason why immigrants might hold more physically demanding jobs. This theory posits that less desirable jobs have to pay higher wages in order to attract workers. At the same time, workers who are less concerned about job disamenities are more willing to work in less desirable jobs (see Rosen 1986 and Hersch and Viscusi 2010 for formal models). Immigrants may be more likely to work in less desirable jobs because they have lower incomes and less wealth than U.S. natives, on average. Immigrants therefore may "purchase” fewer job amenities, such as less physical effort, and may be willing to work in more arduous jobs in exchange for higher wages. Earning a compensating differential might improve workers' perceptions of their working conditions. In addition, immigrants, particularly those from developing countries, may have different expectations about working conditions than U.S. natives. Immigrants might perceive any given job as less physically demanding than natives and thus be more likely to hold physically demanding jobs.

Segmented labor markets theory offers an additional perspective on why immigrants might be more likely to work in physically demanding jobs. Segmented labor markets theory posits that there is an upper tier of good jobs and a lower tier of dead-end, poorly compensated jobs where minorities predominate (Piore 1979). Many immigrants are in the latter, secondary 
market because of their low levels of human and social capital. Under this theory, the embedded structure of the labor market, combined with discrimination, makes it difficult for immigrants to exit the lower tier even as their human and social capital rises with their duration of U.S. residence. If immigrants disproportionately occupy physically intensive jobs, such jobs may become stigmatized, making natives less willing to hold them and thereby entrenching existing differences. Relatedly, Martin (1993) argues that the concentration of immigrants in "dirty” jobs results in hiring networks that exclude natives; at the same time, the ready availability of immigrant workers reduces the need for employers to improve workplace amenities in ways that might make those jobs attractive to natives.

\section{Data and Methods}

This study uses data from several sources to examine differences in physical job requirements between immigrants and U.S. natives and the factors underlying any such differences. The analysis merges data from the 2000 Census 5 percent Public Use Microdata Sample with objective measures of job requirements from the Occupational Information Network (O*NET). Data from the California Work and Health Survey (CWHS) are used to supplement the analysis with self-reported, subjective job requirements. Each of these data sources is discussed in turn.

\section{Census}

The 2000 Census offers a large sample of both natives and immigrants. The sample used here is restricted to people aged 18-59 who worked and had positive earnings the previous year 
and reported a civilian occupation. ${ }^{4}$ To make the data comparable to the CWHS data (described below), the sample is restricted to workers living in California. These restrictions result in a final sample size of 692,362 observations that could be matched to O*NET occupational data (also described below). All of the analysis here is stratified by sex, and observations are weighted using the person weights.

Individuals who report being born abroad and not being a U.S. citizen at birth are considered immigrants in this analysis. Immigrants comprise 35 percent of the male (weighted) sample and 30 percent of the female (weighted) sample. As Table 1 shows, immigrants tend to be younger and less educated than natives and are considerably more likely to speak a language other than English at home. ${ }^{5}$ Immigrants are also more likely to be married and less likely to be divorced/widowed/separated or never married than natives.

California has a considerably higher immigrant share than other states, and its foreignborn population differs from the national average in several noteworthy ways. In 2000, about 28 percent of the foreign-born population lived in California, and 26 percent of the state’s population was foreign born (versus a national average of 11 percent). California has a tremendous concentration of unauthorized immigrants. Almost 32 percent of the unauthorized immigrant population lived in California in 2000, and unauthorized immigrants comprised about 7 percent of the state’s population (Immigration and Naturalization Service 2003). ${ }^{6}$ California’s foreign-born population has lived in the United States longer than the national average. In 2000, 63 percent of California’s immigrants had arrived in the United States 10 or more years ago

\footnotetext{
${ }^{4}$ Results are similar to those shown here if the sample is restricted to ages 25-59.

${ }^{5}$ The Census also has self-reported ability to speak English, but that variable is not used in this analysis since the CWHS does not have an equivalent question. The CWHS asks respondents what language they speak most often at home. The CWHS also asks respondents whether they speak a language other than English at work, but the Census does not have a similar question.

${ }^{6}$ Unauthorized immigrants are included in the Census, although they are believed to be undercounted by 10-15 percent (Hanson 2006). No adjustment is made here for the likely undercount.
} 
compared with 58 percent of immigrants across the entire country. These differences mean that results for California might not be applicable to the entire country. In addition, California might have different work-safety laws than the rest of the country that result in better or worse working conditions. Nonetheless, California is of interest because of its sizable populations of both natives and immigrants.

\section{O*NET}

The objective data on job conditions are from the O*NET, a database of job characteristics sponsored by the U.S. Department of Labor's Employment and Training Administration. This study uses $\mathrm{O}^{*} \mathrm{NET}$ version 4.0, the last version to consist only of ratings from trained analysts, not people actually working in those jobs. ${ }^{7}$ The analyst ratings should reduce any bias that might arise from subjectivity and endogeneity if people working in a particular job rate it differently than the general population would. Analysts rated occupations on a wide variety of characteristics, ranging from necessary skills to work activities, based on information from the Dictionary of Occupational Titles. Analysts rated on a scale of one to five how often an occupation required various tasks and actions and the extent to which various abilities and degrees were necessary for that occupation. The database contains ratings for hundreds of job requirements and characteristics by 6-digit standard occupation classification (SOC) code.

\footnotetext{
${ }^{7}$ The data were released in April 2002. O*NET 4.0 is a release of data first introduced in 1998 converted to the 2000 standard occupation classification system. The $\mathrm{O}^{*} \mathrm{NET}$ data and a detailed description of the database are available on-line at www.onetcenter.org. Peri and Sparber $(2009,2011)$ use O*NET data to examine the effect of immigrant inflows on the distribution of natives across jobs requiring various degrees of manual dexterity, communications, and quantitative skills. Chiswick and Miller (2010) use O*NET data to examine the relationship between occupational English proficiency requirements and workers' self-reported English ability.
} 
This analysis merges the O*NET data on average job conditions with the Census data at the most detailed SOC code available in both datasets, resulting in 470 occupations for men (463 for women) in the combined Census and $\mathrm{O}^{*} \mathrm{NET}$ data. ${ }^{8}$ The analysis assumes that job requirements within detailed occupations are the same for natives and immigrants. If immigrants hold more physically demanding jobs than natives within detailed occupations, as may well be the case, then the results here are biased toward finding smaller immigrant-native differentials than actually exist. The analysis also assumes that physical job requirements in California are the same as the national average. The analysis would be biased if physical job requirements were systematically different across occupations in California relative to national averages in a way related to the immigrant share within occupations in California. For example, if immigrantintensive occupations in California are more physically demanding than those occupations are for the U.S. as a whole, then this analysis will underestimate the extent of native-immigrant differences.

This analysis uses an index based on seven measures of physical job demands from the O*NET that correspond most closely to the measures in the CWHS (discussed below). The index is the sum of the ratings of time spent sitting (recoded here as the inverse, not sitting); walking and running; kneeling, crouching, stooping, or crawling; bending or twisting; using hands to handle, control, or feel objects, tools, or controls; making repetitive motions; and climbing ladders, scaffolds, or poles. Scores in each category range continuously between one and five, so

\footnotetext{
${ }^{8}$ For 64 percent of the observations, the merge is at the most detailed SOC level available in the Census. For the remaining observations, an exact match to the Census SOC is not available in the O*NET data, so the most detailed matching SOC in the O*NET data is used. For 30 percent of the observations, the match is made at one digit above the most detailed SOC level available in the Census (i.e., at the 5-digit level if a match cannot be made at the 6-digit level), and it is made at two digits above the Census SOC for the remaining 6 percent of the observations.
} 
the index ranges from seven to $35 .{ }^{9}$ A higher score means an occupation is more physically intensive.

As Table 1 shows, average physical job requirements are higher for immigrants than for U.S. natives. The immigrant-native difference is about 7.5 percent of the mean for U.S.-born men and 9.6 percent for U.S.-born women. The sample means for the individual items (not shown in the table) indicate that male and female immigrants work in significantly more physically intensive occupations for six of the seven individual measures, or all except walking/running. The biggest immigrant-native differences are in using hands to control tools, making repetitive motions, and not sitting.

\section{California Work and Health Survey}

The CWHS is a longitudinal survey of adults in California conducted in 1998, 1999, and 2000. The survey, which was conducted by telephone, tried to contact earlier participants and also added new adults to the sample in 1999 and 2000. A total of 5983 surveys were conducted among 3805 respondents. The survey purposely oversampled blacks, Asians, and Hispanics. Interviews were conducted in English or Spanish.

The survey includes questions about labor force outcomes and physical job requirements as well as about immigrant and health status. Employed individuals were asked to assess how frequently their job requires them to sit for long periods (recoded here as the inverse, not sitting); walk; kneel, crouch, or stoop; bend over or twist around; use hand tools; repeat the same hand

\footnotetext{
${ }^{9}$ This approach treats the measures as linearly increasing in physical intensity. Ordinal or multinomial models could be used instead, particularly with the CWHS data explained below since they are not continuous. Results based on factor analysis are qualitatively similar to the results shown here.
} 
motion at least 30 times per hour; and use stairs or inclines. ${ }^{10}$ Reponses were given in three categories: not at all, sometimes, and a lot. These ordinal responses are coded here from one to three, with higher scores indicating greater frequency. As with the O*NET data, the analysis focuses on the sum of the scores across these seven categories. This physical job requirements measure can range from seven to 21 .

All people aged 18-59 who reported being currently employed and answered the job requirements and demographics questions are included in the CWHS sample used here, a total of 2962 observations on 2007 individuals. ${ }^{11}$ Observations are weighted here using the CWHS proportional weights that correct for the oversampling of minority groups and make the sample representative of the adult population in California.

Table 2 shows descriptive statistics for the CWHS sample. The weighted sample is 28 percent foreign born for men and 24 percent for women. Lower proportions of the CWHS sample are foreign born and speak a language other than English at home than in the Census sample, perhaps because the CWHS was only conducted in English and Spanish whereas the Census questionnaire was available in five additional languages and language assistance guides were available in 49 additional languages. ${ }^{12}$ The CWHS sample is more likely to have a college degree (bachelor's or higher) and less likely to be married than the Census sample.

\footnotetext{
${ }^{10}$ The CWHS also asked respondents how often their job duties require them to lift or carry weights as heavy as 50 pounds and 10 pounds. Those responses are not examined here since the O*NET does not have a comparable measure of lifting or carrying.

${ }^{11}$ All observations for individuals who appear in the dataset multiple times are included; 1281 individuals appear once, 497 individuals appear twice, and 229 individuals appear 3 times. The standard errors in the CWHS regressions are clustered on the individual to control for individual-specific heteroscedasticity. The results are robust to including only one randomly chosen observation per individual for individuals appear in the survey multiple times with one exception: self-reported physical intensity becomes negatively (positively) related to years in the US (squared) among non-Mexican male immigrants when only one random observation per person is included.

${ }^{12}$ The Census/O*NET results are similar to the results for Mexican immigrants shown in Tables 3 and 5 if the Census sample of immigrants is restricted those who speak English or Spanish (the languages required to participate in the CWHS).
} 
For men, self-reported physical job intensity is slightly lower among immigrants than among natives. Female immigrants and natives report the same level of physical intensity at work. The sample means for the individual items (not shown in the table) indicate that male immigrants report walking, kneeling, and using stairs significantly less often at work than U.S. natives. Female immigrants report kneeling and bending significantly less often at work than U.S. natives.

\section{Methods}

The basic regression estimated here using ordinary least squares (OLS) is

$$
\text { Physical Job Requirements }=\alpha+\beta \text { Immigrant }+\delta \text { Characteristics }+\varepsilon \text {. }
$$

In regressions that use the merged Census and $\mathrm{O}$ *NET data, the values of the dependent variable are from the $\mathrm{O}^{*} \mathrm{NET}$ data on physical job requirements by occupation. All individuals working in a given occupation thus have the same value for the job characteristics in the O*NET data. In regressions that use CWHS data, the values of the dependent variable are self-reported physical job requirements. These values therefore can vary across individuals within an occupation.

The variable Immigrant is an indicator variable equal to one if an individual is an immigrant and zero otherwise. The coefficient on the immigrant indicator variable measures the average difference in physical job requirements between immigrants and natives, controlling for other characteristics. A positive coefficient indicates that physical job requirements are higher among immigrants than among U.S. natives.

The analysis controls for workers' age, education, and marital status. Specifically, the regressions include controls for age and its square; indicator variables for three of four education categories (high school diploma or equivalent, some college, and college degree, with no high 
school diploma as the omitted category); and indicator variables for two of three marital status categories (married and divorced /widowed/separated, with never married as the omitted group). ${ }^{13}$ These specific variables were selected because they are available in both the Census and the CWHS.

For regressions using the Census/O*NET data, standard errors are clustered on the occupation. For regressions using the CWHS data, standard errors are clustered on the individual since individuals can appear in the CWHS up to three times. Regressions using the CWHS data also include year fixed effects for two of the three survey years to control for any business cycle effects or other changes over time.

\section{Results}

\section{Immigrant-Native Differentials}

The first two columns of Table 3 show the estimated coefficients on the immigrant indicator variable in regressions using the merged Census and O*NET data. Each coefficient in the table is from a separate regression. The results indicate that immigrants tend to work in more physically demanding occupations than natives, controlling for age, education, and marital status. Looking first at all immigrant and native workers (top row), the immigrant-native difference is equivalent to 2.3 percent of the sample mean for U.S.-born men, and 5.8 percent for women. Immigrant-native differences in most of the individual measures are statistically significant as well. ${ }^{14}$

\footnotetext{
${ }^{13}$ Age is available in categories in the CWHS and is coded here as the midpoint of each category.

${ }^{14}$ For men as a whole and for non-Mexican immigrant men, the immigrant-native differences are positive and statistically significant for four of seven categories: not sitting, bending, using hand tools, and doing repetitive motions. Among men who have at most a high school diploma or who do not have a high school diploma, the difference in bending becomes statistically insignificant. For Mexican immigrant men, the immigrant-native differences are positive and significant for five categories (all except walking and climbing).For all groups of women, the immigrant-native differences are positive and significant for six categories (all except walking).
} 
The next rows in Table 3 show results for workers who have at most a high school diploma and then for workers who do not have a high school diploma. The immigrant-native differences remain significant, and the gaps are actually larger (both in levels and as a percent of the conditional means) among workers who have not completed high school than among all workers. Differences in physical job intensity between immigrants and natives thus do not appear to be due to differences in educational attainment as measured by high school completion.

The bottom rows in Table 3 show separate results for Mexican and non-Mexican immigrants relative to U.S. natives. Mexicans may be more likely than other immigrants to work in physically intensive occupations given their low education levels and high unauthorized share. For men, this appears to be the case. Male Mexican immigrants work in considerably more physically intensive occupations than natives while non-Mexican immigrants do not. Among women, in contrast, both Mexican and non-Mexican immigrants work in more physically intensive occupations than natives, although the gap is bigger for Mexican women. The Mexican immigrant-U.S. native difference is equivalent to 5 percent of the sample mean for U.S.-born men, and 8.2 percent for women; for non-Mexican immigrant women, the difference is equivalent to 5 percent of the sample mean for U.S. natives. Similar results hold among lesseducated Mexican- and U.S-born workers as well (not shown).

The last two columns of Table 3 report regression results for the self-reported CWHS data. As shown in the top row, male immigrants as a whole actually report being less physically active at work than natives, controlling for observable characteristics (column 3). There is no significant difference for women, although the point estimate in column 4 is negative as well. For both men and women, immigrants report lower significantly levels of physical activity in three of the seven categories: walking, stooping, and climbing stairs for men, and not sitting, 
stooping, and bending for women. ${ }^{15}$ The immigrant-native gap remains negative when looking only at less-educated male workers but is not statistically significant among men who do not have a high school diploma. The immigrant-native gap is smaller for Mexican immigrants (row 4) than for immigrants as a whole, albeit not significantly so given the small sample size and large standard errors in the CWHS. Male non-Mexican immigrants report less physical activity at work than natives report (bottom row).

In results not shown here, age tends not to be significantly related to physical job demands in either the objective or the self-reported data. Both men and women with more education work in less physically arduous jobs, both objectively and subjectively. There is no consistent pattern in how marital status is related to either objective or subjective measures of physical job requirements among men or women.

The Census/O*NET data thus indicate that immigrants work in jobs that are more physically demanding than natives while the CWHS data do not. Why are the results different? One possibility is that workers' subjective ratings of physical intensity systematically differ from the O*NET analysts’ objective ratings. Since workers self-select into jobs, workers in occupations that are objectively more demanding may not find them particularly physically onerous. However, if occupations are ranked in order of increasing physical intensity within each dataset, the ordinal rankings are not statistically different across the two datasets; both Spearman

\footnotetext{
${ }^{15}$ The immigrant-native differences in the other four categories are not statistically significant for men or women as a whole. For workers who have at most completed high school, immigrant men report significantly lower levels of physical activity in four categories (walking, kneeling, bending, and using stairs), and immigrant women report significantly lower levels of walking, kneeling, and bending. For workers who have not completed high school, immigrant men report significantly lower levels of walking and kneeling, and immigrant women report significantly lower levels of bending but significantly higher levels of using stairs. Mexican immigrant-native differences are negative and significant for walking and using stairs for men, and positive and significant for not sitting for women. Non-Mexican immigrant-native differences are negative and significant for walking, kneeling, and using stairs for men, and for walking, bending, and using stairs for women.
} 
and Kendall's tau-b rank correlation coefficients were statistically significant below the 1 percent level. $^{16}$

Another possibility is that the difference is due to differences in immigrants' and natives’ perceptions of physical job requirements. However, occupational rankings of physical intensity by immigrants and by natives are similar in the CWHS data; Spearman and Kendall's tau-b rank correlation coefficients were again statistically significant below the 1 percent level.

Construction was the most physically intensive occupation among both immigrants and natives, and law the least.

Although their rankings of occupations are similar, immigrants working in a given occupation might rate their jobs as less physically intensive than natives working in that same occupation. An immigrant might rate a job as requiring walking “sometimes” while a native working in the same job might rate it as requiring walking “a lot,” for example. To further examine this, equation (1) was estimated using the CWHS data with the addition of occupation fixed effects or occupation and industry fixed effects. The results from these fixed effects regressions indicate whether there are differences in perceived physical intensity between immigrants and natives working in similar sectors.

Table 4 reports the results. Immigrants tend to perceive their jobs as less physically demanding than natives working in the same sector. In every specification, perceptions of physical job demands are lower among immigrant men than among U.S.-born men. There are fewer significant differences among women, but most of the results point toward immigrant women perceiving their jobs as less physically demanding than U.S.-born women. The difference is smallest among women who have not completed high school. Within this group,

\footnotetext{
${ }^{16}$ The Census/O*NET data were collapsed into the 26 occupational categories available in the CWHS for this comparison of rankings.
} 
immigrants appear to perceive their jobs as at least as physically intensive as natives, although any difference within this group again does not reach statistical significance in the small CWHS sample.

Most immigrants thus appear to perceive their jobs to be less physically demanding than natives working in the same sector, despite objective ratings indicating that their jobs are actually more physically demanding. ${ }^{17}$ This difference may arise because of immigrant-native differences in expectations and norms. If so, immigrants' perceptions of their jobs may change over time as they learn more about labor markets and working conditions in the U.S. This analysis therefore next examines determinants of physical job requirements among immigrants only.

\section{Results for Immigrants}

The above analysis focused on immigrant-native differences in physical job requirements. An additional question is how physical job requirements vary among immigrants. As discussed earlier, more recent and unauthorized immigrants may be particularly likely to hold physically demanding jobs. Those who do not speak English well also may be more likely to work in such jobs.

In order to investigate these hypotheses, models using only observations for immigrants were estimated, with variables measuring length of U.S. residence and English language ability added to equation (1). The additional variables are a linear variable measuring years since an individual came to the U.S. and its square, and an indicator variable for whether an individual

\footnotetext{
${ }^{17}$ In results not shown here, Census/O*NET regressions with occupation fixed effects at the same level of occupational detail as the CWHS regressions continue to indicate that immigrants work in more physically demanding jobs than natives. In other words, when looking within the same broad occupation group, the narrow occupation groups in which immigrants are more likely than natives to work are the occupations that are more physically intensive.
} 
speaks a language other than English at home. The regressions also include the measures of education, age, and marital status used earlier.

Table 5 reports the results for the years-in-U.S. and English-language variables. Results for the objective measures of physical job requirements from the Census/O*NET data are in columns 1 and 3, and results for the subjective measures from the CWHS data are in columns 2 and 4. For immigrants as a whole, the longer an immigrant has lived in the United States, the less physical activity his or her job requires (row 1 , columns 1 and 3). This potential assimilation into better jobs slows as men's duration of U.S. residence increases (row 2, column 1). A similar pattern holds among Mexican male and female immigrants and among non-Mexican female immigrants but not among non-Mexican male immigrants; this makes sense since Table 3 indicates that non-Mexican male immigrants do not work in worse jobs than natives. It bears noting that because the analysis uses only cross-sectional data, these years-in-U.S. results will capture any cohort effects as well as any assimilation effects (Borjas 1985, 1995). The pattern of the coefficients could reflect a shift toward less-skilled groups of immigrants over time, as noted by Borjas, rather than assimilation into less physically demanding jobs.

The jobs held by immigrants who speak a language other than English at home are objectively more physically demanding than the jobs held by other immigrants (row 3, columns 1 and 3). Interestingly, this result is driven by non-Mexican immigrants.

In the CWHS sample, immigrants' subjective ratings of the physical intensity of their jobs are not significantly related to how long they have lived in the United States (columns 2 and 4 of Table 5). The difference between the Census/O*NET results and CWHS results thus suggests that more recent immigrants work in more physically demanding jobs than other 
immigrants but do not perceive them as such. ${ }^{18}$ However, differences between the estimated coefficients for the Census/O*NET and CWHS samples cannot be ruled out given the large standard errors of the CWHS estimates.

Perceptions of physical jobs demands are lower among male Mexican immigrants who do not speak English at home than among Mexican immigrants who speak English at home (row 6, column 2). The Census/O*NET result, in contrast, does not indicate any difference between the two groups in objective measures of physical job requirements (row 6, column 1). Differences between the estimates again cannot be ruled out, however. The results in Table 5 thus suggest that more recent, non-English-speaking immigrants work in worse jobs but do not perceive them as such, particularly among Mexicans, but a larger sample is needed to fully ascertain such differences.

\section{Discussion}

This study examines differences in physical job requirements between immigrants and U.S. natives using both objective occupational averages and self-reported, subjective data. The results indicate that immigrants work in occupations that require more physical activity, as measured by occupational averages, but do not self-report higher physical job requirements than natives report. Objective measures indicate that immigrants who arrived more recently and who speak a language other than English work in occupations that are more physically demanding while subjective measures fail to indicate significant differences. The results thus suggest that immigrants do indeed work in worse jobs in terms of required physical effort but do not perceive these jobs as such.

\footnotetext{
${ }^{18}$ However, self-reported physical intensity is negatively (positively) related to years in the US (squared) among non-Mexican male immigrants when only one randomly chosen observation per person is included.
} 
These results may explain why Mexican immigrants do not appear to earn compensating differentials for working in risky jobs, as concluded by Hersch and Viscusi (2010). Immigrants may not require compensating differentials to work in worse or riskier jobs if they perceive such jobs more positively or as less risky than other workers do. In this case, greater dissemination among immigrants of information about occupational risks and workplace safety standards may be warranted. However, the results are also consistent with Dávila, Mora, and González’s (2011) conclusion that limited-English-proficient Hispanic male immigrants earn larger risk premiums than other Hispanic immigrants or U.S. natives. If those workers earn greater compensation for taking risks or working in worse jobs than other workers, they may have a more favorable view of their working conditions than other workers. This would reduce immigrant-native differentials in self-reported working conditions. Distinguishing between these two hypotheses is not possible with the CWHS data, which report earnings in five or six categories instead of exact values. Further research with a larger dataset that includes earnings and self-reported working conditions is needed.

This analysis gives rise to several additional interesting questions for further research. First, there is some evidence of gender and country-of-origin differences in the results. NonMexican male immigrants do not work in more physically demanding jobs than natives, but their female counterparts do; Mexican men and women alike work in more physically demanding jobs than U.S. natives. The roles of ethnic networks and Spanish versus other languages merit further attention, as does the question of whether labor markets are more segmented on the basis of immigrant status for women than for men. Second, this analysis does not examine the direct impact of immigration on working conditions and job demands. Influxes of immigrants could lead to worse working conditions for all workers or to changes in the distribution of jobs such 
that natives actually work in better jobs as immigration increases if immigrants hold the worst jobs. Because the O*NET data are not longitudinal and the CWHS data cover only a three-year period, the datasets used here cannot be used to examine how job conditions have changed over time in response to immigration. Finally, workplace fatality and injury risks are a more critical area for research than physical job intensity. Comparing immigrants’ and natives’ subjective assessments of workplace risks with actual fatality and injury rates is an important area for future research. 


\section{REFERENCES}

Aguilera, Michael B., and Douglas S. Massey. 2003. "Social Capital and the Wages of Mexican Migrants: New Hypothesis and Tests.” Social Forces 82 (December): 671-701.

Antecol, Heather, and Kelly Bedard. 2006. "Unhealthy Assimilation: Why Do Immigrants

Converge to American Health Status Levels?” Demography 43 (May): 337-360.

Berger, Mark C. and Paul E. Gabriel. 1991. "Risk Aversion and the Earnings of US Immigrants and Natives.” Applied Economics 23 (February): 311-318.

Borjas, George J. 1985. “Assimilation, Changes in Cohort Quality, and the Earnings of

Immigrants.” Journal of Labor Economics 3 (October): 463-489. . 1995. "Immigration and Changes in Cohort Quality Revisited: What Happened to

Immigrant Earnings in the 1980s?” Journal of Labor Economics 13 (April): 201-245. . 1999. Heaven’s Door. Princeton: Princeton University Press.

Chiswick, Barry R., and Paul W. Miller. 2010. “Occupational Language Requirements and the Value of English in the US Labor Market.” Journal of Population Economics 23 (January): 353-372.

Dávila, Alberto, Marie T. Mora, and Rebecca González. 2011. “English-Language Proficiency and Occupational Risk Among Hispanic Immigrant Men in the United States.” Industrial Relations 50 (April): 263-296.

Enchautegui, Maria E. 2008. “The Job Quality of U.S. Immigrants.” Industrial Relations 47 (January): 108-113.

Hamermesh, Daniel S. 1998. "Immigration and the Quality of Jobs.” In Help or Hindrance? The Economic Implications of Immigration for African Americans, edited by Daniel S. Hamermesh and Frank D. Bean, pp. 75-106. New York: Russell Sage Foundation. 
Hanson, Gordon H. 2006. “Illegal Migration from Mexico to the United States.” Journal of Economic Literature 44 (December): 869-924.

Hersch, Joni, and W. Kip Viscusi. 2010. "Immigrant Status and the Value of a Statistical Life.” Journal of Human Resources 45 (Summer): 749-771.

Immigration and Naturalization Service. 2003. "Estimates of the Unauthorized Immigrant Population Residing in the United States: 1990 to 2000.” Washington, D.C.: Immigration and Naturalization Service.

Martin, Philip L. 1993. “The Missing Bridge: How Immigrant Networks Keep Americans Out of Dirty Jobs.” Population and Environment 14 (July): 539-565.

Orrenius, Pia M., and Madeline Zavodny. 2009. “Do Immigrants Work in Riskier Jobs?” Demography 46 (August): 535-551.

Peri, Giovanni, and Chad Sparber. 2009. “Task Specialization, Immigration, and Wages.” American Economic Journal: Applied Economics 1 (July): 135-169 , and ___ 2011. "Highly Educated Immigrants and Native Occupational Choice." Industrial Relations 50 (July): 385-411.

Piore, Michael. 1979. Birds of Passage: Migrant Labor and Industrial Societies. Cambridge: Cambridge University Press.

Rosen, Sherwin. 1986. “The Theory of Equalizing Differences.” In Handbook of Labor Economics, edited by Orley Ashenfelter and Richard Layard, pp. 641-692. Amsterdam: North Holland. 
TABLE 1

Descriptive Statistics for Census Sample

\begin{tabular}{lccccc}
\hline & \multicolumn{3}{c}{ Men } & & \multicolumn{2}{c}{ Women } \\
\cline { 2 - 3 } \cline { 5 - 6 } & Natives & Immigrants & & Natives & Immigrants \\
\hline Age & 38.00 & 36.65 & 38.07 & 37.72 \\
High school diploma & 0.21 & 0.16 & 0.19 & 0.17 \\
Some college & 0.38 & 0.19 & 0.43 & 0.25 \\
College degree & 0.31 & 0.22 & 0.31 & 0.25 \\
Married & 0.54 & 0.66 & 0.50 & 0.62 \\
Divorced/widowed/separated & 0.13 & 0.07 & 0.21 & 0.15 \\
Years in U.S. & - & 15.93 & & - & 16.94 \\
Speak non-English language at home & 0.14 & 0.90 & 0.15 & 0.89 \\
Mexican-born & - & 0.50 & & - & 0.38 \\
Physical job requirements & 16.77 & 18.05 & & 15.13 & 16.59 \\
Sample size (unweighted) & 241,141 & 133,228 & 222,709 & 95,284 \\
\hline
\end{tabular}

Source: Author's calculations from 2000 Census (weighted by person weights except as indicated). 
TABLE 2

Descriptive Statistics for CWHS Sample

\begin{tabular}{lccccc}
\hline & \multicolumn{3}{c}{ Men } & & \multicolumn{2}{c}{ Women } \\
\cline { 2 - 3 } & Natives & Immigrants & & Natives & Immigrants \\
\hline Age & 36.81 & 34.61 & 38.12 & 35.73 \\
High school diploma & 0.20 & 0.18 & 0.17 & 0.17 \\
Some college & 0.39 & 0.23 & 0.37 & 0.26 \\
College degree & 0.36 & 0.30 & 0.42 & 0.30 \\
Married & 0.42 & 0.56 & 0.40 & 0.46 \\
Divorced/widowed/separated & 0.16 & 0.05 & 0.20 & 0.20 \\
Years in U.S. & - & 17.08 & & - & 17.76 \\
Speak non-English language at home & 0.03 & 0.69 & 0.02 & 0.67 \\
Mexican-born & - & 0.52 & & - & 0.42 \\
Physical job requirements & 13.87 & 13.76 & & 12.99 & 12.99 \\
Sample size (unweighted) & 1147 & 436 & 1078 & 301 \\
\hline
\end{tabular}

Source: Author's calculations from 1998-2000 California Work and Health Surveys (weighted by person weights except as indicated). 
TABLE 3

Immigrant-Native Differentials in Physical Job Requirements

\begin{tabular}{|c|c|c|c|c|}
\hline & \multicolumn{2}{|c|}{ Census/O*NET } & \multicolumn{2}{|c|}{ CWHS } \\
\hline & $\begin{array}{l}\text { Men } \\
(1)\end{array}$ & $\begin{array}{c}\text { Women } \\
\text { (2) }\end{array}$ & $\begin{array}{l}\text { Men } \\
\text { (3) }\end{array}$ & $\begin{array}{c}\text { Women } \\
(4)\end{array}$ \\
\hline All workers & $\begin{array}{l}0.393^{* *} \\
(0.087)\end{array}$ & $\begin{array}{l}0.884^{* *} \\
(0.108)\end{array}$ & $\begin{array}{l}-0.521^{*} \\
(0.263)\end{array}$ & $\begin{array}{l}-0.357 \\
(0.237)\end{array}$ \\
\hline High school or less education & $\begin{array}{l}0.368 * * \\
(0.130)\end{array}$ & $\begin{array}{l}1.267^{* *} \\
(0.190)\end{array}$ & $\begin{array}{l}-0.895 * * \\
(0.427)\end{array}$ & $\begin{array}{l}-0.482 \\
(0.397)\end{array}$ \\
\hline No high school diploma & $\begin{array}{l}0.524^{* *} \\
(0.161)\end{array}$ & $\begin{array}{l}1.475^{* *} \\
(0.246)\end{array}$ & $\begin{array}{l}-0.425 \\
(0.680)\end{array}$ & $\begin{array}{c}0.185 \\
(0.734)\end{array}$ \\
\hline Mexican immigrants & $\begin{array}{l}0.846^{* *} \\
(0.144)\end{array}$ & $\begin{array}{l}1.248 * * \\
(0.192)\end{array}$ & $\begin{array}{l}-0.120 \\
(0.442)\end{array}$ & $\begin{array}{l}-0.107 \\
(0.374)\end{array}$ \\
\hline Non-Mexican immigrants & $\begin{array}{c}0.084 \\
(0.094) \\
\end{array}$ & $\begin{array}{l}0.762^{* * *} \\
(0.104)\end{array}$ & $\begin{array}{l}-0.859 * * \\
(0.281)\end{array}$ & $\begin{array}{l}-0.483 \\
(0.280)\end{array}$ \\
\hline \multicolumn{5}{|c|}{$\begin{array}{l}* \mathrm{p}<0.05 ; * * \mathrm{p}<0.01 \\
\text { Note: Shown are estimated coefficients on an immigrant indicator variable in OLS regressions. } \\
\text { Each coefficient is from a separate regression. The dependent variable is the sum of scores for } \\
\text { seven measures of physical job requirements from the O*NET or the CHWS; higher scores } \\
\text { indicate doing activities more frequently. Standard errors (in parentheses) are clustered on the } \\
\text { occupation for the Census/O*NET regressions and on the individual for the CWHS regressions. } \\
\text { Regressions include controls for age, age squared, education, and marital status (see text for } \\
\text { details). }\end{array}$} \\
\hline
\end{tabular}


TABLE 4

Immigrant-Native Differentials in Physical Job Requirements, CWHS Data

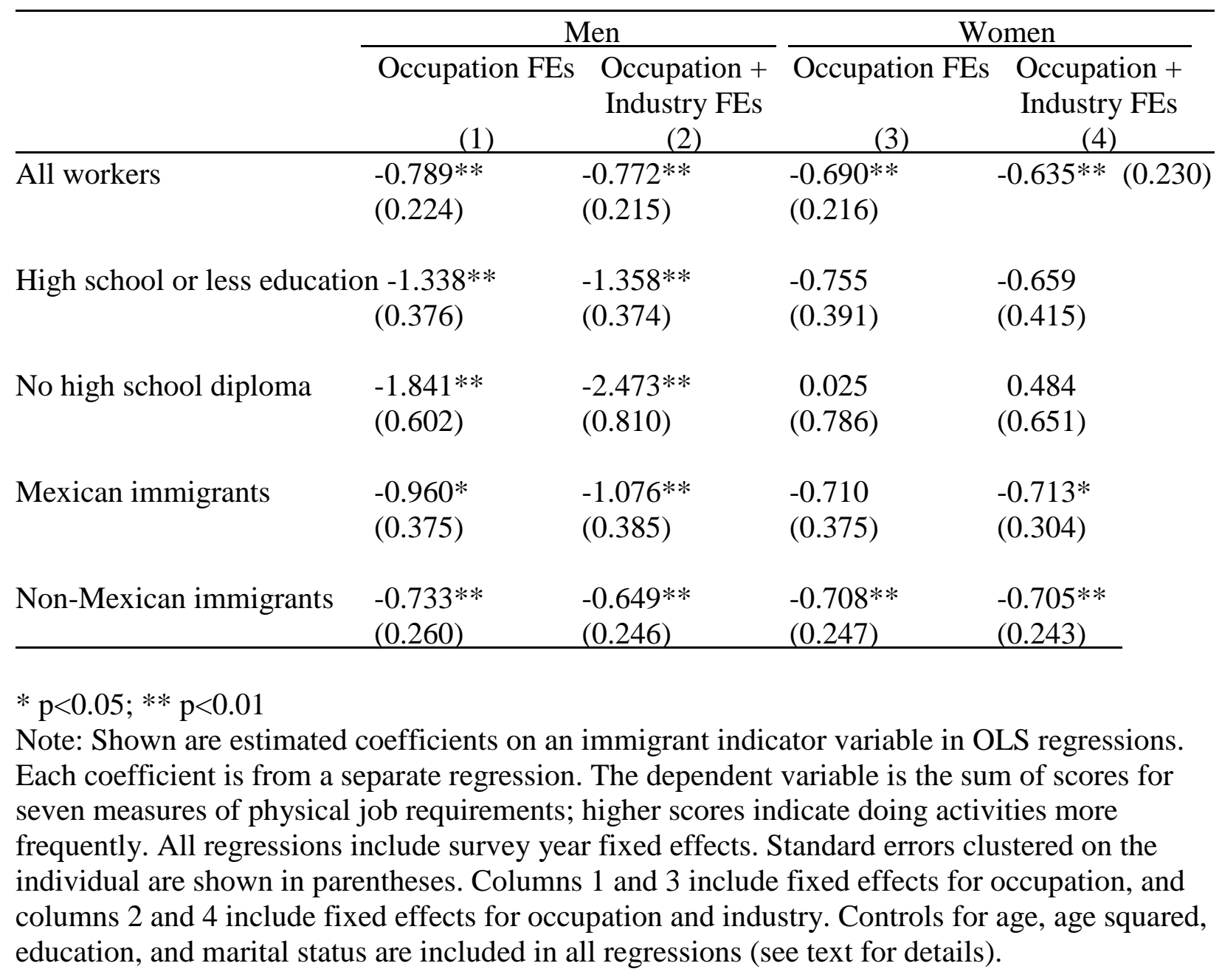


TABLE 5

Determinants of Physical Job Requirements for Immigrants

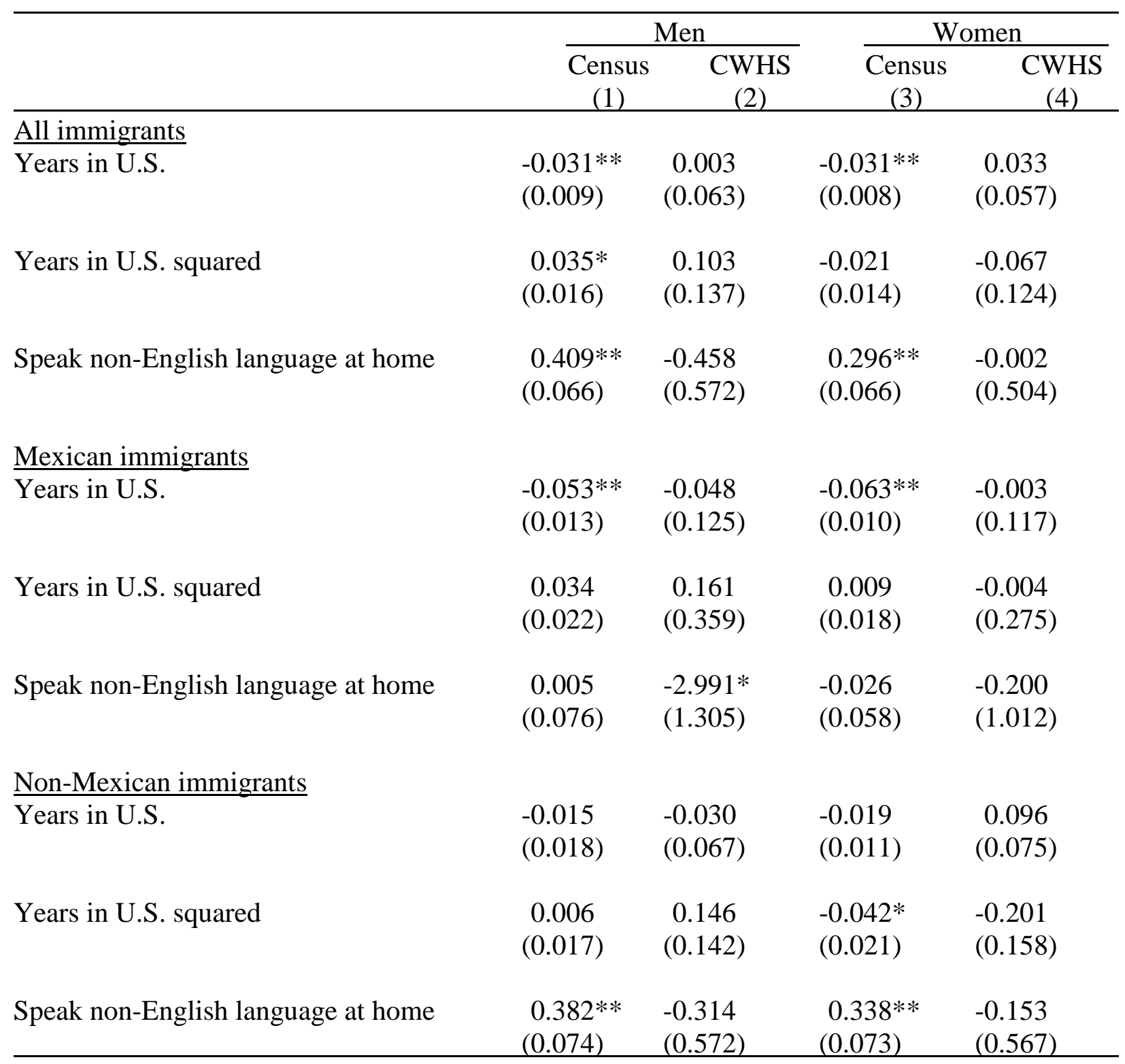

$* \mathrm{p}<0.05 ; * * \mathrm{p}<0.01$

Note: Shown are estimated coefficients from OLS regressions. The dependent variable is the sum of scores for seven measures of physical job requirements; higher scores indicate doing activities more frequently. Each column is from a separate regression. Controls for age, age squared, education, and marital status are included in all regressions, and year fixed effects in columns 2 and 4. Years in U.S. squared is divided by 100 . Standard errors are clustered on the occupation in columns 1 and 3 and on the individual in columns 2 and 4. 